\title{
The Process of Decision-Making in Universities
}

\author{
DAVID J. LAWLESS*
}

\begin{abstract}
Canadian universities are considered by some in the public and private sector to be inefficient organizations, largely because of the inability to make decisions related to cost effectiveness. There is a threat to introduce other control mechanisms into the decision-making autonomy of the universities. In fact, universities are very complex organizations and comparable with other complex systems. They are probably as effective in their operation as other organizations in the public and private sector when they are examined according to a set of criteria of effectiveness. They could be compared on these criteria but full data are lacking. In terms of their autonomy Canadian universities enjoy a greater amount of local decision-making than universities in many other countries. British and German universities, although they are quite different, achieve high standards without the same autonomy as Canadian universities. But are they really as efficient and should we allow ourselves to be pushed in the direction of control to which they are subject or should we resist it?
\end{abstract}

\section{RÉSUMÉ}

Les universités canadiennes sont considérées par certains membres des secteurs publique et privé comme des organisations inefficaces, en grande partie à cause de leur incapacité à prendre des décisions concernant l'efficacité des dépenses. $L$ 'introduction d'autres mécanismes de contrôle dans l'autonomie des universités en ce qui concerne leurs prises de décisions pèse comme une menace. En fait, les universitiés sont des organisations très complexes et comparables à d'autres système complexes. Elles sont probablement aussi efficaces dans leur fonctionnement que d'autres organisations des secteurs publique et privé lorsqu'on les évalue d'après un ensemble de critères d'efficacité. On pourrait les évaluer d'après ces critères, mais des données complètes manquent. En ce qui concerne leur autonomie, les universités canadiennes bénéficient plus du privilège de prendre des décisions locales que les universités de bien d'autres pays. Les universités anglaises et allemandes, quoique très différentes, obtiennent des résultats très satisfaisants sans avoir la même autonomie que les universités canadiennes. Mais sont-elles

* Professor, Department of Psychology, University of Manitoba 
vraiment aussi efficaces? Devrions-nous nous laisser pousser dans la direction du contrôle ququel elles sont soumises ou bien devrions-nous y résister?

\section{INTRODUCTION}

In spite of protestations to the contrary there is a view expressed by the public and by government members that universities are inefficient consumers of their resources. Leslie (1980) for example, reflects this when he states:

The public authorities, frustrated by the apparent unresponsiveness of the universities to exhortations and warnings to take their own affairs in hand and to cooperate with government in the pursuit of cost-control and structural change, may feel it necessary to subject the universities to increasingly tight and pervasive controls. (p. 129)

This sentiment is also echoed by Howard Bowen (Clark Kerr, et al, 1978) and by the Canadian delegation report (all but one of whose members were federal or provincial government employees ${ }^{1}$ ) at a recent OECD (1981) intergovernmental conference which stated under the heading of "New Patterns of Authority":

.... among the obstacles to improved management were the extreme participatory decision-making structures inaugurated in the late 1960's ... . which give small groups the power unreasonably to block decisions that are in the interests of their institutions or of the system as a whole (Working Group 4,p. 4)

Such a view of inefficient decision-making appears to be based on a limited, even simplistic, perception of universities. The perception may stem from assumptions that organizations in the private sector generally manage their affairs efficiently.

The type of decision-making they employ is one of the major differences between universities and other organizations, whether they be in the public or the private sector. It would be legitimate, then, to ask whether the decision making employed by universities contributes to their efficiency or detracts from it and whether, on this basis, there is a case for subjecting the universities "to increasingly tight and pervasive controls".

As a first step I shall outline the general structure and operation of complex organizations, how one determines whether or not they are efficient, and how universities, public sector, and private sector organizations can be compared. As a second step I shall make some selected comparisons between universities in Canada and those in Britain and Germany where decision-making is more centralized.

\section{COMPLEX ORGANIZATIONS}

The complexity of organizations can be measured in simple terms by their number of employees or clients, the amount of their operating budgets, diversity 
of function, complexity of function, or some combination of these factors and others. Major Canadian universities, like other large complex organizations, employ a staff of 3-4-5,000 people or more; they enrol $20-30$, or more, thousands of students; and they have operating budgets in excess of $\$ 100,000,000$. The functions of universities include the education and training of every type of society's professional members and intelligensia as well as the development and storage of information and science; and within them are conducted the most complex types of analysis, research, and scholarship. They can be numbered among the more complex human organizations.

All complex organizations have some form or other of bureaucratic structure. This is unavoidable wherever specialization and coordination is required, as in the training of professional students, and requires some hierarchy of command, however limited, with some officers being responsible for the direction and coordination of the work of others. The more specialized and complex the work that is done in the organization, the more difficult the work of direction and coordination becomes for those in the hierarchy who are responsible for overall objectives. Given the complexity of universities this makes the work of those who plan, coordinate and direct the academic enterprise extremely difficult and makes the selection of criteria for effective operation both difficult and subject to challenge. Added to this is a firmly rooted tradition of peer judgment and collective decision-making in the Canadian university, a tradition which predates the "participatory decision-making structures inaugurated in the late 1960 's" but which that movement greatly elaborated upon and strengthened.

In comparing universities to other organizations one might look at military colleges run by the Department of National Defence; at community colleges operated by provincial governments but with significant money available through the federal government; at training and research programs operated by federal ministries (e.g. Department of Transport); or at training and research programs operated by a small number of private organizations in Canada.

Good comparative data on costs, outputs, and effectiveness of these systems is non-existent. However, it is unlikely that the universities rank at the bottom end of the scale in effectiveness. The universities probably stand at a higher level on the scale of effectiveness than the others, at least in response to long-term needs. Although I believe the effectiveness of my own university compares favorably with any military college, community college, federal ministerial training and research program, or the small number of training-research programs of the private sector with which I am familiar, my comparison could be challenged: if it were based solely on personal perceptions.

\section{INDICES OF EFFECTIVENESS}

How might one go about making such a comparison? The information and theoretical suggestions are rather thin, although Cameron (1978) has set out nine indices of effectiveness specifically for the comparison of institutions of higher education, and again (Cameron 1981) outlines four domains of organizational 
effectiveness for colleges and universities to consider. Six generally measurable variables of effectiveness have been set out in some detail by the author elsewhere. ${ }^{2}$ These six factors are: productivity, morale, conformity, adaptiveness, institutionalization, and stability. On the assumption that most people have a general understanding of three of these (i.e. productivity, morale, and adaptiveness) only the other three will be described.

Conformity refers to whether or not the behavior of people within the organization complies with the ideology reflected in the rules and norms of the organization. In universities, the question would be whether professors and other members behave in such a way as to support the acknowledged objectives of a university. Lack of conformity would see defiance and sabotage of accepted norms of teaching, research, and service. Few organizations have as many of their members so fully and personally dedicated and committed to upholding their purposes and values as do universities.

Institutionalization refers to whether or not an organization receives the support of the society in which it is embedded. In Canada we are getting a mixed review on this measurement at the moment for student applications for admissions have risen in most fields and are very high in a number of technical and professional fields; private donations to universities are probably higher than at any time in history; students are willing to absorb higher tuition and incidental costs; private organizations and government agencies are courting us and purchasing our services; yet governments have publicly whipped and threatened us in recent years.

The third measurable variable is stability and it is the one that truly distinguishes us from private sector and most public sector organizations. The maintenance of stability requires universities to operate with balanced budgets, to maintain those programs which students and the public demand even though they are very costly, and to avoid disruption of programs by such things as strikes and lockouts which are disruptive to student progress. To maintain stability and prevent its own destruction during bad times in the private sector, an organization can raise prices, close down branch operations, lay off staff, sell off subsidiaries, borrow money, and so forth. In the public sector organizations can often count on supplementary estimates. What can universities do? They do raise prices modestly by increasing tuition fees, although some are not permitted to do so unilaterally, by charging lab fees, by selling class notes, by raising food prices and parking fees, and so forth. Most universities have been under serious constraints from constituents, clients, and governments, however, in taking these price increases too far or too fast. Among other things, voices of concern are raised that the long battle for greater accessibility to the universities would be curtailed by rapid rises in fees and other costs. As for closing down branch operations, universities find there are very few programs which can be sacrificed without a serious blow to quality or without producing a public outcry. Already the course offerings in some departments have become restricted or are available on an alternate year basis. We may have to go further and close down, for example, honours programs in many departments. Laying off staff has its special problems 
in universities as we all know, in spite of university and faculty union declarations that tenure is not job security. (Governments, of course, have their own problems in getting rid of non-producers.) As for selling off subsidiaries and borrowing money from the bank, there is very little scope for the universities.

\section{THE NATURE OF DECISION-MAKING IN CANADIAN UNIVERSITIES}

Decision-making in Canadian universities is based on a different tradition than found in other public sector organizations and in private, profit-making organizations. It calls for decision by vote following an open debate of the facts and issues by all those holding professorial rank. Although debate tended to be dominated in the past by senior members of the legislative body, all had a right to full participation and could invoke the rules of parliamentary debate in their defence. The long-standing practice of general faculty council, senate, conseil, faculty council and departmental council which employed these procedures was extended in the late $60^{\prime} \mathrm{s}$ to boards of governors and other academic committees. The process was also declared public, open to the media, and with accessible minutes. Now it is not uncommon in the Canadian university to see students and junior members of the body fully involved in the debate, with frequent calls for ruling from the chair, and an invocation of parliamentary procedures.

Procedures such as these are foreign to most organizations outside the university. In both public and private sector, decisions on policy and its implementation are made behind closed doors, by senior members, without votes or recourse to parliamentary procedures, and with limited consultation rather than with open debate.

Because of extensive public debate (sometimes reported in the press), referral back of committee reports to further sub-committees, split-vote decision, obviously divided opinion, and delay in implementation of new programs or policies, it may appear that the university is an overly cumbersome and inefficient system.

Canadian universities are fiercely jealous of the decision-making system they have developed and resist any threat to it which could be construed as weakening their autonomy. Yet the financial restraints of recent years have placed provincial governments in a position of ambivalence as to whether they might intrude on this autonomy, and have left universities in an ambivalent position in respect to accepting seductive offers from government where it might relieve financial pressure. In the short run both will probably give a little; in the long run the odds favor government.

\section{OTHER UNIVERSITY SYSTEMS}

Universities throughout the Western World are currently enduring similar problems. Discussing the problems of decision-making with academic administrators in Canadian, British, American and German universities today, for example, 
produces a strong sensation of déjà $\nu u$. Yet the responses to those problems differ, primarily because the context within which decisions are made differ.

The very number of American institutions and the range of their diversity makes it difficult to stereotype the American system. Canadian, British, and German decision-making systems, however, give us a starting point to explore the issue of different styles of response to similar problems. Each can profit from one another's experience and in spite of the rigidities built into each system, each can move a bit in the incorporation of ideas from the others. Accepting that each university within its national system is unique, one can still describe national stereotypes of university decision-making.

The Canadian systems are in the separate control of the ten provinces, there being no national ministry of education or its equivalent and the only coordinating body, the Committee of Ministers of Education of Canada sans Federal Government representation lacking any national authority, the provinces have worked out unique relationships between universities and the funding agencies which provide $90 \%$ of their operating budgets. The Federal Government stands gnashing its teeth in the background claiming to have provided the greater part of the $90 \%$ while being an invisible non-participant in its distribution. The typical internal university distribution of these funds follows historical academic priorities or those determined through open discussion and debate in a series of sub-committees, senate (or general faculty council) committees, presidential advisory committees, the senate itself, and the board of governors. Discussion at each level tends to be open and is often contentious. Motions and amendments are made with recourse to parliamentary procedures, challenges to the ruling of the chair are made, an open vote is taken, and the decision is passed on to the next higher body for similar treatment.

This contrasts with the British system with its flatter bureaucratic structure. Universities in Britain are not large hence it is possible for the astute British vicechancellor to maintain a flatter bureaucracy, keeping direct contact with key department heads while using pro-vice-chancellors and deans in a supportive but non-bureaucratic role. It is unlikely that the vice-chancellor will be challenged in committee or on the floor of senatus largely because a good amount of premeeting agreement has been worked out and lines are drawn before the formal meeting. The placing of motions or amendments and the taking of votes is considered very bad form in most British academic settings, hence the vice-chancellor can "summarize the consensus" without the necessity of a vote, something which his Canadian counterpart could do only under special circumstances and only once or twice in a typical five-year term of appointment. The British administrative infrastructure is different, however, than one typically finds in a Canadian university. The vice-chancellor has frequent direct contacts with a range of non-academic administrators who are his supportive arms and fingers. In the Canadian drama these players tend to be two and three times removed in the bureaucracy. 
The German system lacks the autonomy of both the Canadian and the British system yet is more akin the British system relative to the status of academic appointments and more akin the Canadian system relative a provincial-federal relationship. Canadian academics would be horrified to find that key members of the university administration were appointees of government and that permanent academic staff were on the direct payroll of the government ministry of education. This would probably not raise British eyebrows. Yet the control of university budgets and development as the responsibility of the Land government would be as familiar to a Canadian academic as it would be alien to the British. There are ten Land governments as there are ten provincial governments and each has its ministry of education, as in Canada. The Land governments, however, have surrendered a part of their authority to a federal ministry of education to allow for coordination of national needs and priorities. Within the German system there is not the same sense of need for the type of autonomy enjoyed in Canada and Britain, and there is a willingness to accept that the government coordinates program offerings, the government sets budgets, and the government sets academic priorities. It is further accepted that the kanzler, the government's appointee to the senior university administration, can make or influence decisions which in Canada would require extensive debate and formal recommendation through a series of committees.

In very general terms, we might compare the three systems as follows:

TABLE I : GOVERNMENT INFLUENCE ON THE UNIVERSITIES

\begin{tabular}{l|l|l|c}
\hline SPHERE OF INFLUENCE & Canada & United Kingdom & Germany \\
\hline $\begin{array}{l}\text { Planning by Central } \\
\text { Government }\end{array}$ & NO & MAINLY BUT NOT & ENTIRELY \\
\hline $\begin{array}{l}\text { Appointment of Academics } \\
\text { and/or Conditions of } \\
\text { Appointment }\end{array}$ & NO & SOME & YES \\
\hline $\begin{array}{l}\text { Central Admission of } \\
\text { Students }\end{array}$ & NO & SOME & YES \\
\hline $\begin{array}{l}\text { Central Coordination } \\
\text { of Programs }\end{array}$ & SOME & YES & YES \\
\hline
\end{tabular}

There are other differences, of course, but those noted are sufficient to suggest some directions which we might expect Canadian universities to be pressed. 
British and German academics are as competent as Canadian academics and they have the same sense of personal and academic freedom. The students who are graduated and the services which are provided by universities in Britain and Germany are as good as those in Canada. Then, it may be asked, why would Canadian universities and Canadian academics resist centralized planning of university systems; government involvement in academic appointments, including salary ranges and benefits; the centralized coordination of student admissions; and the centralized coordination of academic program development? We will probably find many good reasons to resist being pressed in these directions but those who call for more control and coordination will be able to point to examples where government control and involvement takes place without the loss of efficiency.

If Canadian academics are convinced that the decisions on planning, appointments, student admissions, and program development should remain the prerogative of the individual universities, then I think they are going to have to make the case that the current system is at least as efficient as systems where there is centralized coordination or control. Right now we do not have the data to make that case. Using the six measures of effectiveness outlined earlier productivity, morale, conformity, adaptiveness, institutionalization, and stability, we should be able to establish some index of effectiveness of Canadian universities. The next step would be to demonstrate that, in spite of a quite different type of decision-making process, the universities are as effective as other public and private organizations, and as effective as universities in non-Canadian systems. This sounds like a big task and it is, but I suspect that a good deal of the data already exist. Much of it has been gathered in Europe (e.g. Hecquet and Jadot, 1978). Until someone comes up with a comparative analysis the suggestions that our universities are inefficient decision makers are going to continue, and accompanying the suggestions will be the threat that control and coordination of major decisions should be put into the hands of others.

\section{FOOTNOTES}

1 The Head of Delegation was a deputy minister of education, the Chairman of the Working Group was a provincial higher education commission chairman, and the Rapporteur was a provincial program director. Of the eleven Canadian participants, one was a university president, two were from the Secretary of State, and the remainder were with the provincial ministries.

2 David J. Lawless: Organizational Behavior, Prentice-Hall, 1979, p. 32-36.

\section{REFERENCES}

Cameron, K.S., Measuring organizational effectiveness in institutions of higher education; Administrative Studies Quarterly, 1978, 23, 604-632.

Cameron, K.S., Domains of organizational effectiveness in colleges and universities, Academy of Management Journal, 1981, 24, 25-47. 
9 The Process of Decision-Making in Universities

Hecquet, I. and Jadot, J., The Impact on University Management of Financing and Control Systems for Higher Education; Joint Project of OECD/CERI and AUPELF; OECD, Paris, 1978.

Kerr, Clark et al; Measurements of Efficiency (12 Systems of Higher Education: 6 Decisive Issues; International Council for Educational Development, New York, 1978.

Leslie, Peter M., Canadian Universities - 1980 and Beyond, AUCC, Ottawa, 1980.

OECD, 1981. Organization for Economic Cooperation and Development, Intergovernmental Conference on Policies for Higher Education in the Eighties, October 1981, Paris; Canadian Delegation Report, December 1981, (mimeo). 